\title{
Advances in microbial remediation for heavy metal treatment: a mini review
}

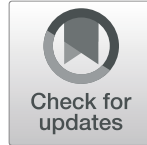

Shipei Wang ${ }^{\dagger}$, Ting Liu ${ }^{\dagger}$, Xiao Xiao and Shenglian Luo ${ }^{*}$ (I)

\begin{abstract}
In recent years, microbiological treatment to remediate contamination by heavy metals has aroused public attention as such pollution has seriously threatens ecosystems and human health and impedes sustainable development. However, the aspect of actual industrial wastewater and solid waste remediation by microorganisms is not explored sufficiently. And what we focus on is technical field of microbial remediation. Therefore, in this review, we discuss and summarize heavy metal treatment via microbiological approaches in different media, including wastewater, solid waste from industrial factories and polluted sites. We also clarify the technical applicability from the perspective of biosorption, bioleaching, biominerization, etc. In particular, the exploration of the combination of microbiological approaches with chemical methods or phytoextraction are scrutinized in this review relative to real waste heavy metal remediation. Furthermore, we highlight the importance of hyperaccumulator endophytes.
\end{abstract}

Keywords: Heavy metals, Biological treatment application, Hyperaccumulator endophytes

\section{Introduction}

Heavy metals are usually released by different anthropogenic sources such as nonferrous metallurgical industry, mining, mineral processing, electroplating, leather tanning, chemical industry, etc. [1-3]. The contamination by heavy metals has received global attention as water contamination has caused serious negative effects on human health through bioaccumulation in the food chain. Large volumes of wastewater originated from the metallurgical processes, and the effluent produced by the nonferrous metallurgical industry are around 730 million tons per year in China $[4,5]$. Therefore, wastewater from nonferrous metallurgical industry is the major source of heavy metals. Approximately 10 million tons of electroplating sludge are produced annually in China [6], which is the secondary solid waste arising out of the precipitation of rinse water and spent electrolytes/etchants in the

\footnotetext{
* Correspondence: sllou@hnu.edu.cn

†Shipei Wang and Ting Liu contributed equally to this work and should be considered co-first authors.

Key laboratory of Jiangxi Province for Persistent Pollutants Control and Resources Recycle, Nanchang Hangkong University, Nanchang 330063, People's Republic of China
}

\section{Springer Open}

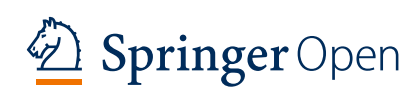

electroplating treatment industries $[7,8]$. Tannery sludge contains diverse undesirable substances such as organics, inorganics, metallic elements $[9,10]$. It is currently a huge challenge to remediate tannery sludge consists of high concentration chromium [11].

Recently, a series of technologies, such as chemical precipitation, electrochemical treatment, reverse osmosis, ion-exchange, physical adsorption and membrane filtration have been developed to remove heavy metal ions from liquid waste, which focus on reducing metal bioavailability by transforming the heavy metal to the a less toxic state $[3,12]$. Several treatment schemes have been proposed for solid waste, such as landfilling [13], chemical leaching [14], stabilization/solidification [15], extraction [16], etc. However, most of technologies appear to be expensive, inefficient, or the treatment process lacks selectivity, and are especially ineffective at low metal concentrations. Bioremediation is a promising technology that uses living green plants or microorganisms to remove pollutants from soils, surface water and groundwater. Microorganisms can also detoxify metals by bioreduction, biosorption, bioleaching, biomineralization, etc. Biosorption/bioaccumulation is the most widely

(c) The Author(s). 2021 Open Access This article is licensed under a Creative Commons Attribution 4.0 International License, which permits use, sharing, adaptation, distribution and reproduction in any medium or format, as long as you give appropriate credit to the original author(s) and the source, provide a link to the Creative Commons licence, and indicate if changes were made. The images or other third party material in this article are included in the article's Creative Commons licence, unless indicated otherwise in a credit line to the material. If material is not included in the article's Creative Commons licence and your intended use is not permitted by statutory regulation or exceeds the permitted use, you will need to obtain permission directly from the copyright holder. To view a copy of this licence, visit http://creativecommons.org/licenses/by/4.0/. 
biotechnique to remove metal ions form effluent, among which pollutants could be adsorbed onto the walls of microbial cell by (1) precipitation, (2) chelation, (3) complexation, or (4) ionic interactions [17, 18]. Recently, bioleaching is developed to recycle different metals in the treated leachate or residues via leaching them from solid wastes [19, 20]. In addition, biomineralization usually refers to a process of precipitation of mineral materials, by which microbes transform aqueous metal ions into amorphous or crystalline precipitates [21].

Hitherto, biological technologies based on microorganisms for heavy metal waste treatment has received considerable and growing attention over the years [22, 23], because of outstanding advantages, including high efficiency, low cost, and environment friendly. The metabolic diversity and activity of microorganisms has allowed their commercial exploitation in the field of waste cleanup (Fig. 1). Previous studies focused on the isolation and application of microbes with heavy metal resistance in synthetic heavy metal solutions. Nevertheless, nowadays researchers prefer pilot or large-scale waste treatment in actual (i.e., real) case, or using pollutants from industrial plants and contaminated sites. As a result, we have summarized the heavy metal treatment by microbial technology in both wastewater and discharged solid pollutants from industrial plants and polluted sites. Likewise, we need to focus on the biotechniques applicability from the perspective of technical field of microbial remediation. Subsequently, the exploitation of hyperaccumulator endophytes as an efficient bioremediation strategy is discussed.

\section{Biological treatment of heavy metal in different types of waste}

\subsection{Electroplating effluent and sludge}

The electroplating industry produces a variety of metallic coatings, ranging from technological to decorative applications, discharges large amounts of wastewater contaminated with heavy metals, which is of environmental concern due to their high toxicity $[24,25]$. However, most of traditional techniques for electroplating effluent treatment have drawbacks such as low removal efficiency and production of large amounts of sludge, which has been identified as hazardous waste because of the high-concentration of potentially toxic metals $[26,27]$. Therefore, a combination of biological and conventional approach is a proper strategy to decontaminate metal pollutant for the remediation of electroplating wastewater and sludge.

Several studies have been conducted on the treatment of metals in electroplating effluent using different biological methods, as summarized in Table 1. Ye et al. [29] reported metal removal from aqueous solutions (including $\mathrm{Cr}, \mathrm{Cu}, \mathrm{Ni}$ and $\mathrm{Zn}$ ) by the mixture of Candida lipolytica and dewatered sewage sludge. The biosorption of $\mathrm{Cr}$ increased the live C. lipolytica extracellular secreta

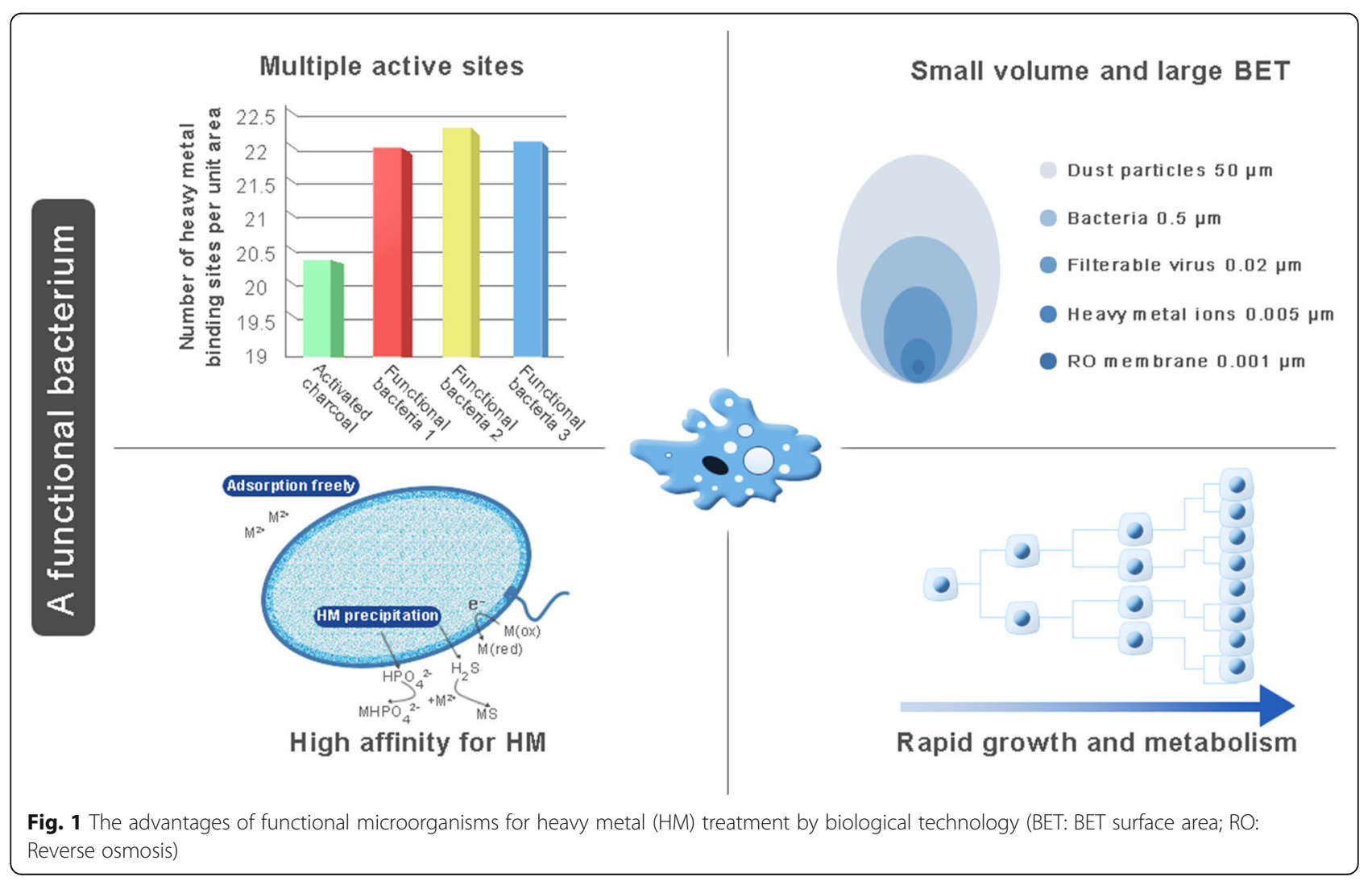


Table 1 Assessment and biological treatment of heavy metals in different liquid/solid waste

\begin{tabular}{|c|c|c|c|c|c|}
\hline & Microbes or mixtures & $\begin{array}{l}\text { Pollution } \\
\text { source }\end{array}$ & Capacity/Efficiency & $\begin{array}{l}\text { Effect/ } \\
\text { Mechanisms }\end{array}$ & Reference \\
\hline $\begin{array}{l}\text { Mixtures of } \\
\text { microbes }\end{array}$ & $\begin{array}{l}\text { Leptospirillum ferriphilum CS13, } \\
\text { Acidithiobacillus caldus S2, Sulfobacillus } \\
\text { acidophilus S5, }\end{array}$ & $\begin{array}{l}\text { Electroplating } \\
\text { sludge }\end{array}$ & $\begin{array}{l}\text { Removal rate of various heavy metals } \\
\text { was over } 99 \%\end{array}$ & Bioleaching & {$[28]$} \\
\hline \multirow{3}{*}{$\begin{array}{l}\text { Mixtures of } \\
\text { microbes and } \\
\text { sludge }\end{array}$} & Water treatment sludge & $\begin{array}{l}\text { Electroplating } \\
\text { wastewater }\end{array}$ & $\begin{array}{l}\mathrm{Cu}^{2+} \text { and } \mathrm{Cr}^{6+} \text { adsorption capacities } \\
\text { are about } 1.7 \text { and } 3.5 \mathrm{mg} \mathrm{g}^{-1}\end{array}$ & Biosorption & {$[21]$} \\
\hline & $\begin{array}{l}\text { Mixture of Candida lipolytica and sewage } \\
\text { sludge }\end{array}$ & $\begin{array}{l}\text { Electroplating } \\
\text { wastewater }\end{array}$ & $6.66 \mathrm{mg} \mathrm{g}^{-1}$ & $\begin{array}{l}\text { Bioreduction and } \\
\text { biosorption }\end{array}$ & {$[25]$} \\
\hline & $\begin{array}{l}\text { Sulfate-reducing bacteria ( } 43.3 \% \text { of } \\
\text { Desulfovibiro) enriched sludge }\end{array}$ & $\begin{array}{l}\text { Electroplating } \\
\text { effluent }\end{array}$ & $100 \%$ within $3 d$ & $\begin{array}{l}\text { Biological } \\
\text { precipitation }\end{array}$ & [26] \\
\hline \multirow[t]{2}{*}{$\begin{array}{l}\text { Main bacteria } \\
\text { strains }\end{array}$} & Acidithiobacillus ferrooxidans & $\begin{array}{l}\text { Dewatered } \\
\text { metal plating } \\
\text { sludge }\end{array}$ & $\begin{array}{l}\text { Metal solubilization: } 97 \% \text { of } \mathrm{Zn}, 96 \% \\
\text { of } \mathrm{Cu}, 93 \% \text { of } \mathrm{Ni}, 84 \% \text { of } \mathrm{Pb}, 67 \% \text { of } \\
\mathrm{Cd} \text { and } 34 \% \text { of } \mathrm{Cr} \text { in } 20 \text { days }\end{array}$ & Bioleaching & {$[27]$} \\
\hline & Acidithiobacillus ferrooxidans & $\begin{array}{l}\text { Electroplating } \\
\text { sludge }\end{array}$ & $\begin{array}{l}\text { Cr: } 80.9 \% \text { and Ni: } 65.8 \% \text { (with acid } \\
\text { leaching) }+6.0 \% \mathrm{Cr} \text { and } 11.7 \% \mathrm{Ni} \\
\text { (additional extraction by bioleaching) }\end{array}$ & $\begin{array}{l}\text { Combined } \\
\text { bioleaching and } \\
\text { acid leaching }\end{array}$ & {$[29]$} \\
\hline \multirow[t]{3}{*}{ Single culture } & Arthrobacter sp. X34 & \multirow{3}{*}{$\begin{array}{l}\text { Simulated } \\
\text { groundwater }\end{array}$} & 0 & \multirow[t]{3}{*}{ Biomineralization } & \multirow[t]{3}{*}[20]{} \\
\hline & Bacillus sp. Y9-2 & & $73 \%$ precipitated in 5 days & & \\
\hline & Rahnella sp. Y9602 & & 95\% precipitated in 5 days & & \\
\hline $\begin{array}{l}\text { Mixtures of } \\
\text { microalgae } \\
\text { and } \\
\text { bioresource }\end{array}$ & Chlorella vulgaris and calcined eggshells & $\begin{array}{l}\text { Acid mine } \\
\text { drainage }\end{array}$ & $\begin{array}{l}99.7 \% \text { of } \mathrm{Fe}, 99.5 \% \text { of } \mathrm{Cu}, 99.9 \% \text { of } \mathrm{Zn} \text {, } \\
99.8 \% \text { of } \mathrm{Mn}, 100 \% \text { of } \mathrm{As} \text {, and } 100 \% \\
\text { of } \mathrm{Cd} \text { in } 6 \text { days }\end{array}$ & Biosorption & [30] \\
\hline $\begin{array}{l}\text { Mixtures of } \\
\text { microbes }\end{array}$ & Sulfate-reducing bacteria & $\begin{array}{l}\text { Underground } \\
\text { mine drainage }\end{array}$ & $\begin{array}{l}90.5 \% \text { of } \mathrm{Cd} \\
89.3 \% \text { of } \mathrm{Zn}\end{array}$ & Biomineralization & {$[31]$} \\
\hline Single culture & Acidithiobacillus ferrooxidans & $\begin{array}{l}\text { Synthetic acid } \\
\text { mine drainage }\end{array}$ & $\begin{array}{l}53.62 \% \text { of } \mathrm{Fe} \\
17.27 \% \text { of As }\end{array}$ & Biomineralization & {$[32]$} \\
\hline $\begin{array}{l}\text { Mixtures of } \\
\text { microbes }\end{array}$ & $\begin{array}{l}\text { Bacillus subtilis ITSUKMW1, Acinetobacter junii } \\
\text { VITSUKMW2, and Escherichia coli } \\
\text { VITSUKMW3 }\end{array}$ & $\begin{array}{l}\text { Synthetic } \mathrm{Cr}^{6+} \\
\text { solution }\end{array}$ & $\begin{array}{l}99 \% \text { reduction of } \mathrm{Cr}^{6+}\left(100 \mathrm{mg} \mathrm{L}^{-1}\right) \text { in } \\
64 \mathrm{~h}\end{array}$ & Bioreduction & [33] \\
\hline $\begin{array}{l}\text { Mixtures of } \\
\text { microbes }\end{array}$ & $\begin{array}{l}\text { Ferrovum, Thiomonas, Gallionella, } \\
\text { Leptospirillum }\end{array}$ & $\begin{array}{l}\text { Sb-rich mine } \\
\text { water }\end{array}$ & $\begin{array}{l}90 \% \text { of total Sb, } \\
80 \% \text { of } \mathrm{Sb}(\mathrm{III})\end{array}$ & $\begin{array}{l}\text { Biological } \\
\text { precipitation and } \\
\text { biotransformation }\end{array}$ & {$[34]$} \\
\hline $\begin{array}{l}\text { Single culture } \\
\text { or mixtures }\end{array}$ & Bacillus cereus Pseudomonas putida & $\begin{array}{l}\text { Tannery } \\
\text { effluent }\end{array}$ & $51.9 \%$ of $\mathrm{Cr}(\mathrm{VI})$ & Bioreduction & {$[35]$} \\
\hline $\begin{array}{l}\text { Immobilized } \\
\text { fungi Mixtures }\end{array}$ & $\begin{array}{l}\text { Cladosporeum perangustum, Penicillium } \\
\text { commune, Paecilomyces lilacinus, Fusarium } \\
\text { equiseti }\end{array}$ & $\begin{array}{l}\text { Tannery } \\
\text { wastewater }\end{array}$ & $\begin{array}{l}100 \% \text { of } \mathrm{Cr}(\mathrm{Vl}), 99.92 \% \text { of total } \mathrm{Cr} \text {, } \\
95.91 \% \text { total } \mathrm{Pb}, 100 \% \text { of } \mathrm{Pb}(\mathrm{II})\end{array}$ & Biosorption & {$[36]$} \\
\hline $\begin{array}{l}\text { Mixtures of } \\
\text { microbes }\end{array}$ & $\begin{array}{l}\text { Acidithiobacillus ferrooxidans LX5, } \\
\text { Acidithiobacillus thiooxidans TS6 }\end{array}$ & $\begin{array}{l}\text { Bioleachate } \\
\text { derived from } \\
\text { tannery } \\
\text { sludge }\end{array}$ & $\begin{array}{l}\text { Chromium-iron agent was bioleached } \\
\text { from bioleachate }\end{array}$ & $\begin{array}{l}\text { Bioleaching and } \\
\text { recycling }\end{array}$ & [37] \\
\hline $\begin{array}{l}\text { Actinomycete } \\
\text { single culture }\end{array}$ & Kitasatosporia sp & $\begin{array}{l}\text { Tannery } \\
\text { wastewater }\end{array}$ & $\begin{array}{l}100 \% \text { of } \mathrm{Cr}(\mathrm{VI}) \\
98 \% \text { of } \mathrm{Cr}(\mathrm{III}) \text { precipitation }\end{array}$ & $\begin{array}{l}\text { Biosorption and } \\
\text { chemical } \\
\text { precipitation }\end{array}$ & {$[38]$} \\
\hline $\begin{array}{l}\text { Mixed } \\
\text { microbes }\end{array}$ & $\begin{array}{l}\text { Stenotrophomonas sp. WY601, Proteus } \\
\text { mirabilis, Microbacterium paraoxydans, } \\
\text { Bacterium FX2, Bacillus tequilensis }\end{array}$ & $\begin{array}{l}\text { Tannery } \\
\text { sludge }\end{array}$ & $\begin{array}{l}90 \% \text { of } \mathrm{Cr}(\mathrm{VI}) \text { within } \\
65 \mathrm{~h} \text { (single culture of WY601) }\end{array}$ & Bioreduction & [39] \\
\hline $\begin{array}{l}\text { Mixed plants } \\
\text { and } \\
\text { endophytic } \\
\text { bacteria }\end{array}$ & $\begin{array}{l}\text { Mixture of Leptochloa fusca and Pantoea } \\
\text { stewartii ASI11, Microbacterium arborescens } \\
\text { HU33, Enterobacter sp. U38, }\end{array}$ & $\begin{array}{l}\text { Tannery } \\
\text { effluent }\end{array}$ & $\begin{array}{l}135 \pm 4.2,19 \pm 1.3,8550 \pm 42,450 \pm \\
9.5,174 \pm 3.1,15 \pm 0.72,11 \pm 0.21,5 \pm \\
0.29,7 \pm 0.65\left(\mathrm{mg} \mathrm{kg}^{-1} \text { Root) }\right.\end{array}$ & $\begin{array}{l}\text { Bioaccumulation } \\
\text { and } \\
\text { phytoextraction }\end{array}$ & {$[40]$} \\
\hline $\begin{array}{l}\text { Mixed plants } \\
\text { and } \\
\text { endophytic } \\
\text { bacteria }\end{array}$ & $\begin{array}{l}\text { Pantoea sp. strain TYRI15, Microbacterium } \\
\text { arborescens TYSIO4; Bacillus endophyticus } \\
\text { PISI25, Bacillus pumilus PIRI30, Bacillus sp }\end{array}$ & Textile effluent & $\begin{array}{l}97 \% \text { of } \mathrm{Cr}, 89 \% \text { of } \mathrm{Fe}, 88 \% \text { of } \mathrm{Ni}, 72 \% \\
\text { of } \mathrm{Cd}\end{array}$ & $\begin{array}{l}\text { Bioaccumulation } \\
\text { and } \\
\text { phytoextraction }\end{array}$ & {$[41]$} \\
\hline
\end{tabular}


slime layers and decreased the intracellular synthesis of metal binding proteins or peptides. However, only aluminum-based water treatment sludge was assessed for removal of high concentrations of $\mathrm{Cu}$ and $\mathrm{Cr}$ (VI) from an electroplating wastewater along with other heavy metals [24]. Two continuous-flow pilot-scale systems were used to demonstrate that sulfate-reducing bacteria-based metal process could not only remove sulfate and nickel with low cost and less sludge, but also facilitate the subsequent removal of total phosphorus and nitrogen [28]. The main genera in the sulfate-reducing bacteria community were Desulfovibiro (relative abundance of $43.3 \%$ ). In summary, the microbes enriched from activated sludge is a better choice for treatment of actual plating wastewater containing various wastes.

Electroplating sludge is a potential secondary resource. Earlier, to compare the microbial and chemical leaching technique to recover heavy metals in dewatered electroplating sludge, Bayat and Sari [42] studied the bioleaching of sludge involving Acidithiobacillus ferrooxidans in a completely mixed batch reactor. Their results illustrated that $\mathrm{Zn}, \mathrm{Cu}, \mathrm{Ni}$ and $\mathrm{Pb}$ had good solubilization efficiency (84-97\%) during the bioleaching process, but $\mathrm{Cd}$ and $\mathrm{Cr}$ solubilization was relatively low (67\% and $34 \%$, respectively). Recently, combined microbial and acid leaching was followed for sludge treatment because acid leaching could reduce the toxicity of heavy metals in electroplating sludge [43]. The solubilized $\mathrm{Cr}$ content (80.9\%) was improved compared to the former research (Table 1). The bio-treatment of electroplating sludge was also investigated for bioleaching of metals by mixed microbes (Leptospirillum ferriphilum CS13, Acidithiobacillus caldus S2, Sulfobacillus acidophilus S5) at semipilot scale [44]. A $300 \mathrm{~L}$ aerated packed reactor was designed to effectively leach heavy metals from electroplating sludge within a few hours using the mixed microbial stock solution.

\subsection{Pollution of mining waste}

The booming economy in China has led to scale expansion of mining in the past decades. Nonferrous mining can impact water and soil quality according to the chemical composition of the ores and waste dump materials [30]. Mining wastewater is a kind of mine impacted water composed of mine drainage, open cast mining and waste rock yard drainage, most of which contains high concentrations of sulfate and heavy metals. Mine impacted waters can be acidic (acid mine drainage, AMD), or with $\mathrm{pH}$ values ranging from 6 to 9 defined as neutral mine drainage (NMD) [31]. Moreover, mine impacted waters could be treated by abiotic and biotic means which can be classified as active and passive treatments [32].

Many research reports are available on the heavy metal pollution from mine areas worldwide, as summarized in
Table 1. AMD is a major environmental problem that is greatly contaminating water bodies in and around abandoned mine area. A pilot scale AMD treatment plant was built at the Yongdong mine located in South Korea. The effluent contained excess $\mathrm{Fe}, \mathrm{Cu}, \mathrm{Zn}, \mathrm{Mn}$, As, and $\mathrm{Cd}$. A hybrid system containing calcined eggshells and microalgae was used to remove heavy metals from AMD in a 40-L bioreactor [45]. The results showed that the simultaneous removal of $\mathrm{Fe}, \mathrm{Cu}, \mathrm{Zn}, \mathrm{Mn}$, As, and $\mathrm{Cd}$ from the AMD effluent was 99 to $100 \%$ in 6 days. A semi-passive experiment mimicking the belowground insitu conditions was carried out at Silver King mine site in Canada, where leaching of $\mathrm{Zn}$ and Cd occurs. Metals were removed from underground mine drainage (it was NMD) fed into the $200 \mathrm{~L}$ bioreactors, $\mathrm{Zn}$ and $\mathrm{Cd}$ removal extent was $20.9 \%$ and $39 \%$ in winter, respectively. However, the $\mathrm{Zn}$ and $\mathrm{Cd}$ removal efficiency increased to $89.3 \%$ and $90.5 \%$ in summer, respectively [34]. Given that the influent average concentration of $\mathrm{Zn}$ and $\mathrm{Cd}$ was $640.4 \mu \mathrm{g} / \mathrm{L}$ and $10.5 \mu \mathrm{g} / \mathrm{L}$ respectively, this biological approach could only be applied in the low metal concentration for groundwater treatment. In order to enhance lime neutralization with AMD by reducing the production of ferric hydroxide and waste gypsum, a microbial enhanced-lime neutralization passive treatment technology was developed for AMD on a semi-pilot scale [33]. This system promoted As (III) in solution adsorption by minerals and transformation of soluble $\mathrm{Fe}$ and $\mathrm{SO}_{4}{ }^{2-}$ into secondary iron minerals by biomineralization with A. ferrooxidans.

There are more than $114 \mathrm{Sb}$ mines in China, accounting for approximately $90 \%$ of global Sb production [46]. Thus, remediation of Sb-rich mine water is generally regarded as a priority issue for local government. Sun et al. [47], designed an onsite field-scale bioreactor system (consisted of five treatment tanks) to passively treat $\mathrm{Sb}$ mine contaminated water in Southwest China. The polluted water came from an active upstream $\mathrm{Sb}$ mine that produces $8-25 \mathrm{~m}^{3} / \mathrm{d}$ of mine water with up to 7 $\mathrm{mg} / \mathrm{L}$ soluble Sb (III). With the aerobic tanks inoculated with indigenous mine water microorganisms, the bioreactor removed more than $90 \%$ of total soluble $\mathrm{Sb}$ and $80 \%$ of soluble $\mathrm{Sb}$ (III). Three indigenous bacteria were isolated from chromite mining sites in India. The development of sequential processes (isolated $\rightarrow$ acclimatized $\rightarrow$ consortia) improving $\mathrm{Cr}$ (VI) resistant isolates, proved to be a feasible microbial reduction approach for the specific chromite mine [48].

\subsection{Leather tanning effluent and sludge}

Both leather production and consumption are developing fast in China. In order to convert raw skin/hides into leather, approximately $80 \%$ of chromium-containing tanning agents have been utilized in the leather-based 
industries $[49,50]$. The enforceable maximum contaminant level of total chromium in drinking water and public water systems is $50-100 \mu \mathrm{g} / \mathrm{L}$ [51], whereas chromium in industrial discharge ranges from 0.1 to $400 \mathrm{mg} / \mathrm{L}$. [52] Consequently, treatment of tanning effluent for contamination alleviation becomes urgent and necessary. Chromium is a transition metal with wide industrial application, existing in oxidation states of bivalent to hexavalent. The trivalent and hexavalent forms are the most stable among the major oxidation states of chromium [53]. Compared with $\mathrm{Cr}$ (III), Cr (VI) is considered to be more toxic due to its high solubility and mobility. In addition, $\mathrm{Cr}$ (VI) is both genotoxic and carcinogenic, identified as one of the chemicals causing a threat to human health [35]. Several studies have shown that $\mathrm{Cr}$ (III) compounds at high concentrations cause oxidatively-generated DNA damage [36]. Hence, any form of chromate removal/recycling is an alternative option to the conventional reduction of chromium, especially the treatment of whole real tannery waste, as summarized in Table 1.

For every $20 \%$ of leather produced from raw material, more than $72 \%$ of the chromium from tanning agents is converted into solid and liquid waste [38]. Thus, microbial reduction of $\mathrm{Cr}$ (VI) from tannery solid and liquid waste has been studied by many researchers. Nutrients required for microbial metabolism, such as carbon/energy and nitrogen sources are scanty in real tannery effluent. Supplementation with such nutrients was proved to increase the efficiency of bioremediation [37]. Tannery effluent decolorization, dechlorination, and $\mathrm{Cr}^{6+}$ remediation were obtained with $0.8 \%$ glucose and $0.2 \%$ ammonium chloride $(\mathrm{w} / \mathrm{w})$ in 3:1 diluted wastewater within $3 \mathrm{~d}$ of Bacillus cereus incubation. Simultaneously, effluent bioremediation was attempted with an immobilized coculture of B. cereus and Pseudomonas putida, which enhanced the remediation of $\mathrm{Cr}^{6+}$ (51.9\%) compared to the single culture removal (41.7\%). Apart from bacteria, filamentous fungi are an attractive option for tanning waste treatment. High-strength tannery wastewaters treatment by nylon mesh immobilized fungal inocula in a stirred tank bioreactor demonstrated good reduction in different contamination parameters within 120 h, e.g. COD (82.52\%), color (86.19\%), Cr (VI) (100\%), Total Cr (99.92\%), Pb (II)(100\%), Total Pb (95.91\%) and $\mathrm{NO}_{3}{ }^{-}(9.94 \%)$ [39].

Some researches focused on developing effective resource utilization of leather waste. For example, a combined chemical-biological system was designed for $\mathrm{Cr}$ remediation and reclamation. Lime and cement dust were used for chemical precipitation of $\mathrm{Cr}$ (III) that was recycled in the leather tanning, while the actinomycete Kitasatosporia sp. was used in a vertical glass column filled with porous media for Cr (VI) adsorption [54]. Ma et al. [55] reported chromium recovery of bioleachate derived from tannery sludge by microbial leaching and its reuse, and a chromium-iron tanning agent was developed to reduce the costs of $\mathrm{Cr}$ and Fe separation. Chromium-iron tanned leather showed equivalent to around one year's natural aging of heat aging properties after hot air aging tests. Resource utilization of leather processing wastes is probably a potential way in the future. Due to microbial consumption of organic matter, the amount of the tannery sludge was decreased by $27 \%$ with culturing mixed bacteria (five $\mathrm{Cr}$ resistant strains) anaerobically for $14 \mathrm{~d}$ [56]. Chromate (VI) reductase was found to be localized inside the extracellular membrane or adsorbed to its surface. This is probably a mechanism for the removal of Cr (VI) via Stenotrophomonas sp.

\section{Exploitation of hyperaccumulating endophytic microbes as an efficient heavy metal bioremediation strategy}

\subsection{Endophytes isolation and characterization}

Heavy metal hyperaccumulators, particularly those inhabiting in contaminated areas, are plant species capable of absorbing much larger amounts of metal compounds than general plants. Endophytic microbes inhabit internal tissues of hyperaccumulators and form a range of different relationships with the host plant, including symbiotic, mutualistic, and trophobiotic without causing disease. In such plant-bacteria combination, plants support the microbial community, and in return, microbes improve plant growth and pollutant detoxification. Hence, these hyperaccumulator endophytes also exhibit higher heavy metal tolerance and accumulating abilities compared to other microorganisms [57-59]. Endophytes from heavily polluted sites with radionuclides and other toxic heavy metals may be potentially rich bioresources in heavy metal decontamination. We can exploit the endophytic microorganisms as an effective bioremediation strategy. Earlier, a bacterium strain LRE07 (Serratia sp.) was isolated from the root of the cadmium hyperaccumulator Solanum nigrum L., which could bind cadmium and zinc efficiently in its growing microbial cells both in single-ion and multi-ions system [58]. However, $S$. nigrum L. inoculated with an endophyte Pseudomonas sp. Lk9 isolated from its host plant, increased phytoextraction rates of all metals from multi-metal contaminated soils $(17.4 \%, 48.6 \%$ and $104.6 \%$ for $\mathrm{Cd}, \mathrm{Zn}$ and $\mathrm{Cu}$, respectively) [59]. A total of 14 bacterial endophytes were isolated from Alnus firma root and assayed for tolerance to lead, among which isolate MN3-4 was identified as Bacillus sp. [60]. Moreover, Bacillus MN3-4 could produce siderophores and indoleacetic acid to transform the $\mathrm{Pb}$ form in soils or increase $\mathrm{Pb}$ accumulation by plants. 


\subsection{Endophytes with plant growth promoting properties} Plant growth promoting endophytes (PGPE), identified as precious bioresources in bioaugmentation with phytoremediation, promote plant growth and heavy metal uptake via various mechanisms. Many isolates from hyperaccumulators have been proved for their plant growth promoting (PGP) features as well as their resistance to different heavy metals [61-63]. Four Cdresistant endophytic strains assisted their host plants to cope with toxicity stress responses. They produced indole-3-acetic acid (IAA),1-aminocyclopropane-1-carboxylic deaminase, phosphate solubilizing activity and siderophores, which were identified as plant growth promoting mechanisms [40]. Multiple heavy metal-resistant $(\mathrm{Cd}, \mathrm{Zn}, \mathrm{Pb}$ and $\mathrm{Cu})$ PGPE from root nodules of Robinia pseudoacacia in a mining area were selected to improve phytoremediation efficiency. Mesorhizobium loti HZ76 and Agrobacterium radiobacter HZ6 were symbiotic with the highest potential for heavy metal resistance and PGP properties [41]. Besides bacteria, the stressmitigating effects of endophytic fungi have been investigated. Penicillium funiculosum LHL06, isolated from soybean roots, could help the host plants to modulate physio-biochemical, molecular, and proteomic responses to multiple heavy metals $(\mathrm{Ni}, \mathrm{Cu}, \mathrm{Pb}, \mathrm{Cr}$, and $\mathrm{Al})$ toxicity [64]. Fungus LHL06 can upregulate gibberellins, IAA production and downregulate heavy metal ATPase genes in its host plants compared to non-fungi-inoculated plants.

\subsection{Application of endophytic microbes in real contaminants}

A plant-bacterial system with constructed wetlands (CWs) was developed for the efficient remediation of tannery effluent, among which three different endophytic bacteria were used for bioaugmentation [65]. The results showed that the combined use of plants and endophytes lead to enhanced performance of heavy metal ( $\mathrm{Cr}, \mathrm{Fe}, \mathrm{Mn}, \mathrm{Ni}, \mathrm{Pb}, \mathrm{Ba}, \mathrm{Cd}$, and $\mathrm{Co}$ ) removal from wastewater compared to the plants only, as summarized in Table 1. The combined utilization of the salt-tolerant plant Leptochloa fusca and the chromium-resistant endophytes Prosopis juliflora (bacteria from another plant) for tannery effluent treatment was the highlight of this study. Another pilot-scale vertical flow constructed wetlands setup was likewise implemented to treat dye-rich real textile effluent for one year. The endophyte-assisted CWs promoted a substantial removal of heavy metals (Cr 97\%, Fe 89\%, Ni 88\%, Cd 72\%), simultaneously, decreased chemical oxygen demand (81\%), biochemical oxygen demand (72\%), color (74\%), nitrogen $(84 \%)$ and phosphorus (79\%) [66]. The above-mentioned study could likely be applied in future field-scale and timeeffective bioremediation of real industrial effluent consisted of organic and inorganic contaminants. Plants inoculated with different consortia were used to carry out an endophyte-assisted phytoremediation experiment in a metal contaminated mine soil $[67,68]$. Inoculation of endophytes improved the plants' physiological status by increasing the chlorophylls and carotenoids content. Moreover, positive influence of plant growth and endophyte inoculation on soil characteristics were reflected in PGB features, such as higher values of acid phosphatase activity, microbial community diversity, etc. The phytoremediation of vanadium-contaminated soil was elevated via affecting the rhizosphere and endosphere microecosystem by endophyte inoculant.

\section{Biological technique patterns applicable principles}

As shown in Table 2, we analyzed and organized the techniques applicability, heavy metal form, and concentration range involved in this study. Biosorption can be applied using live or dead organism, which include bacteria, fungi, algae, actinomycete. Microorganism combine with different bioresource as biosorbents adsorb and accumulate heavy metals (soluble form) from wastewater or acid mine drainage under low to moderate concentration. Microbial leaching is suitable for extracting metals (insoluble form) from secondary resources. Bioleaching not only decrease the amount of sludge to be disposed of but also prevent release of metals into the environment. Acidithiobacillus ferrooxidans and Acidithiobacillus thiooxidans are widely employed in the bioleaching process [42, 43, 55]. But various microbes like Pseudomonas fluorescens [69], Leptospirillum ferriphilum [70], and Aspergillus niger [71] have been tested for metals bioleaching. Biomineralization, ubiquitous in nature, is a process of mineral crystal formation induced/ controlled by microbes. Sulfate-reducing bacteria, A. ferrooxidans and urease-positive fungi play a potential role in the synthesis of novel biominerals (schwertmannite, calcite, otavite) that can remove toxic metal As or $\mathrm{Cd}$ [33, 34, 72]. Microorganisms can also detoxify metals by bioreduction (e.g., $\mathrm{Cr}$ (VI) to $\mathrm{Cr}$ (III), $\mathrm{SeO}_{4}{ }^{2-}$ to $\mathrm{Se}$ ), the valence of metal ions is transformed during the process. In cleaning up heavy metal-contaminated water or soils (soluble form), phytoextraction is typically employed together with bioaccumulation by endophytes. The approach is suitable for large, low contamination areas in situ.

\section{Conclusions}

We have compared the advantages and disadvantages of biological approaches in Table 2. Biological or other technologies for purifying or recycling real wastes containing heavy metals have their own strength and weakness. Thus, the future trend is to develop treatment of 


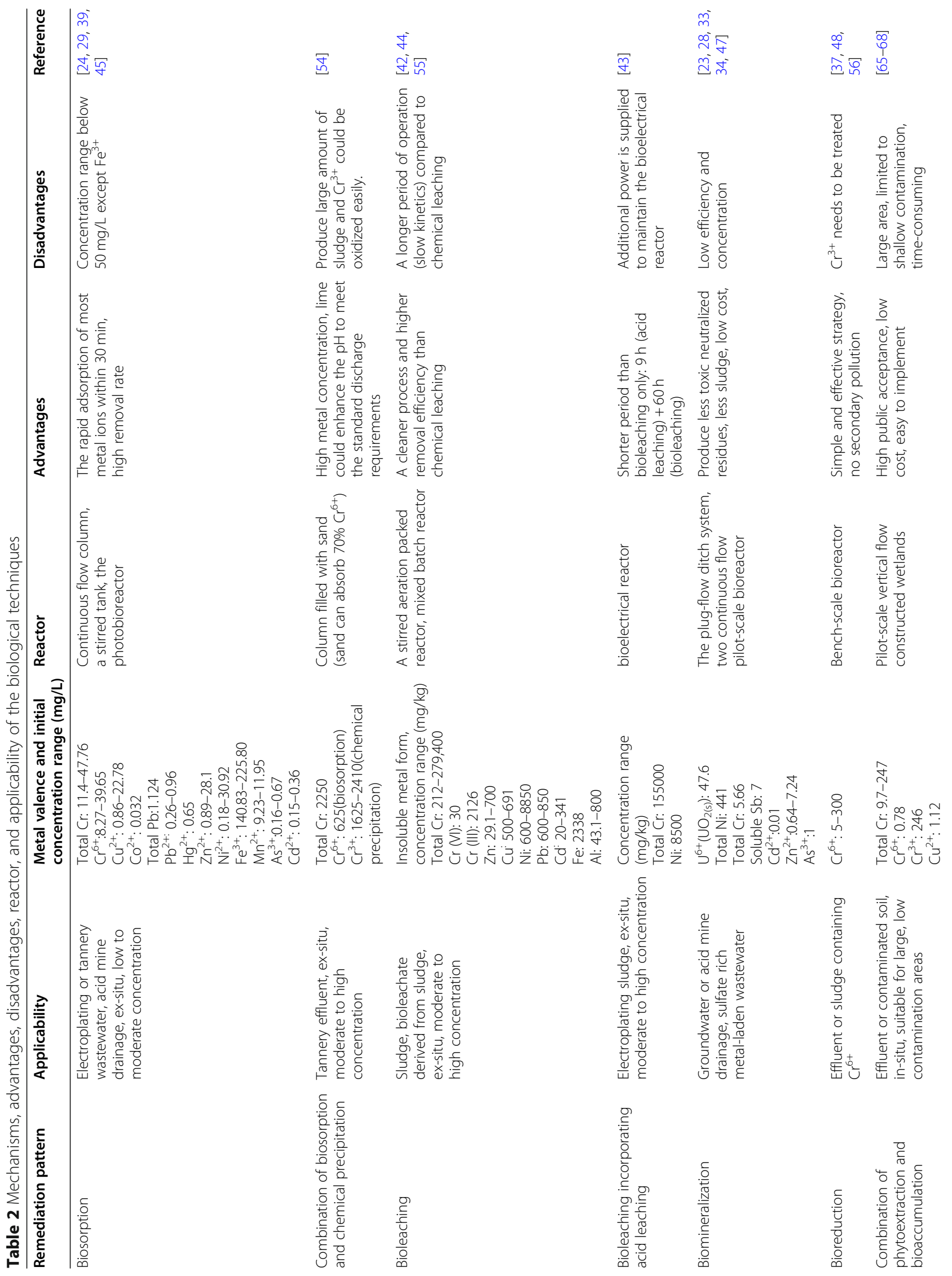




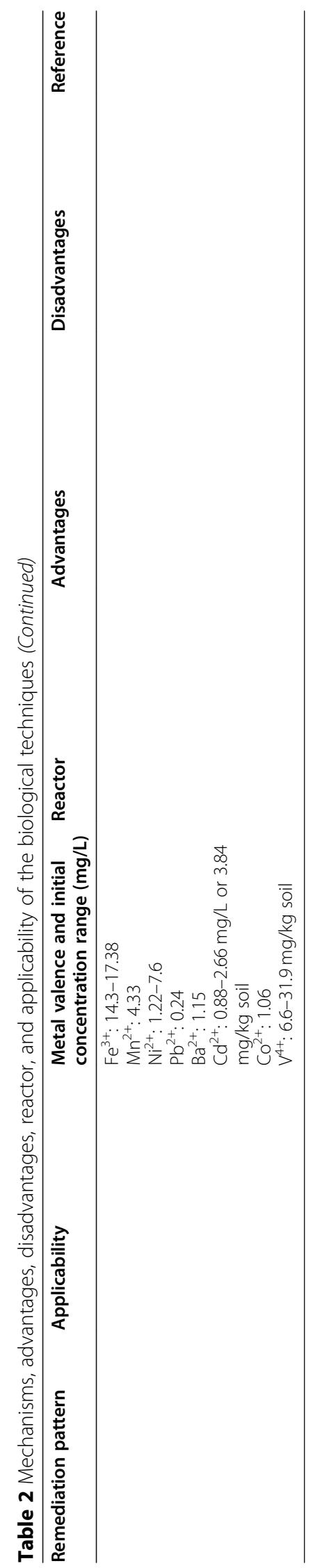


heavy metals by the combination of multiple approaches to exploit the optimum experimental protocol which benefit from the vantage and avoid the shortcomings. In addition, a very limited number of field applications have been performed for heavy metal bioremediation. Consequently, research for future technology enhancement should be aimed at evaluating the feasibility of industrial waste treatment at large scale and application of on-site treatment systems. Then try to resolve problems of field engineering application.

\section{Abbreviations}

C. lipolytica: Candida lipolytica; AMD: Acid mine drainage; NMD: Neutral mine drainage; A. ferrooxidans: Acidithiobacillus ferrooxidans; B. cereus: Bacillus cereus; PGPE: Plant growth promoting endophytes; PGP: Plant growth promoting; IAA: Indole-3-acetic acid; CWs: Constructed wetlands

\section{Acknowledgements}

The authors are grateful to the National Natural Science Foundation of China (Grant NO. 51968048). We appreciate that Dr. Pavlostathis from Georgia Institute of Technology gives valuable comments on our manuscript for concision and clarity.

\section{Authors' contributions}

Luo $S$ conceived and designed this manuscript and made substantial contributions to the revision of this work. Wang $S$ interpreted data from references and wrote the original manuscript. Liu T wrote and revised the original manuscript substantively. Xiao $X$ designed Fig. 1, graphical abstract and summarized Table 1 and 2. All authors read and approved the final edition.

\section{Funding}

National Natural Science Foundation of China (Grant NO. 51968048).

\section{Availability of data and materials}

The data of Table 1 in this study is available in the references, which has been mentioned in the article.

\section{Competing interests}

No conflict of interest exits with the submission of this manuscript, and the manuscript is approved for publication by all authors.

\section{Received: 23 April 2020 Accepted: 2 October 2020}

Published online: 15 January 2021

\section{References}

1. Nouha K, Kumar RS, Tyagi RD. Heavy metals removal from wastewater using extracellular polymeric substances produced by Cloacibacterium normanense in wastewater sludge supplemented with crude glycerol and study of extracellular polymeric substances extraction by different methods. Bioresour Technol. 2016;212:120-9.

2. Liu SH, Zeng GM, Niu QY, Liu Y, Zhou L, Jiang LH, Tan X, Xu P, Zhang C, Cheng M. Bioremediation mechanisms of combined pollution of PAHs and heavy metals by bacteria and fungi: a mini review. Bioresour Technol. 2017;224:25-33.

3. Ayangbenro AS, Babalola OO. A new strategy for heavy metal polluted environments: a review of microbial biosorbents. Int J Environ Res Public Health. 2017;14(1):94

4. Cai R, Gao C, Zhang J, Huang X. Resource and utilization of metallurgical wastewater. J Salt Chem Ind. 2013:42:1-7.

5. Wu P, Jiang LY, He Z, Song Y. Treatment of metallurgical industry wastewater for organic contaminant removal in China: status, challenges, and perspectives. Environ Sci Wat Res Technol. 2017;3(6):1015-31.

6. Lu H, Yu S. Spatio-temporal variational characteristics analysis of heavy metalspollution in water of the typical northern rivers, China. J Hydrol. 2018; 559:787-93.

7. Li P, Peng C, Li F, Song S, Juan A. Copper and nickel recovery from electroplating sludge by the process of acid-leaching and electrodepositing. Int J Environ Res. 2011;5(3):797-804.
8. Peng G, Tian G. Using electrode electrolytes to enhance electrokinetic removal of heavy metals from electroplating sludge. Chem Eng J. 2010; 165(2):388-94.

9. Tang P, Zhao Y, Xia F. Thermal behaviors and heavy metal vaporization of phosphatized tannery sludge in incineration process. J Environ Sci. 2008; 20(9):1146-52.

10. Goswami L, Mukhopadhyay R, Bhattacharya SS, Das P, Goswami R. Detoxification of chromium-rich tannery industry sludge by Eudrillus eugeniae: insight on compost quality fortification and microbial enrichment. Bioresour Technol. 2018;266:472-81.

11. Yang YL, Ma HR, Chen XP, Zhu C, Li X. Effect of incineration temperature on chromium speciation in real chromium-rich tannery sludge under air atmosphere. Environ Res. 2020. https://doi.org/10.1016/j.envres109159.

12. Azimi A, Azari A, Rezakazemi M, Ansarpour M. Removal of heavy metals from industrial wastewaters: a review. ChemBioEng Rev. 2017;4(1):37-59.

13. Fei Y, Liu C. Chapter 12 - Detoxification and Resource Recovery of Chromium-Containing Wastes, Editor(s): M.N.V. Prasad, Kaimin Shih, Environmental Materials and Waste, Academic Press, 2016. p. 265-284. ISBN 9780128038376. https://doi.org/10.1016/B978-0-12-803837-6.00012-3.

14. Wang F, Yu J, Xiong W, Xu YL, Chi R. A two-step leaching method designed based on chemical fraction distribution of the heavy metals for selective leaching of $\mathrm{Cd}, \mathrm{Zn}, \mathrm{Cu}$, and $\mathrm{Pb}$ from metallurgical sludge. Environ Sci Pollut Res. 2018;25(2):1752-65.

15. Rocha RDCD, Zorel HE, Lando T. Use of experimental design in the study of galvanic sludge immobilization in red ceramic for environmental impact minimization. Cerâmica. 2017;63:1-10.

16. Pant D, Joshi D, Upreti MK, Kotnala RK. Chemical and biological extraction of metals present in E waste: a hybrid technology. Waste Manag. 2012;32(5):979-90

17. Podstawczyk D, Witek-Krowiak A, Dawiec A, Bhatnagar A. Biosorption of copper (II) ions by flax meal: empirical modeling and process optimization by response surface methodology (RSM) and artificial neural network (ANN) simulation. Ecol Eng. 2015;83:364-79.

18. Li D, Xu X, Yu H, Han X. Characterization of $\mathrm{pb}^{2+}$ biosorption by psychrotrophic strain Pseudomonas sp. I3 isolated from permafrost soil of Mohe wetland in Northeast China. J Environ Manag. 2017;196:8-15.

19. Zeng J, Gou M, Tang Y, Li G, Sun Z, Kida K. Effective bioleaching of chromium in tannery sludge with an enriched sulfur-oxidizing bacterial community. Bioresour Technol. 2016;218:859e866.

20. Dunbart WS. Biotechnology and the mine of tomorrow. Trends Biotechnol. 2017:35:79e89

21. Dhami NK, Quirin ME, Mukherjee A. Carbonate biomineralization and heavy metal remediation by calcifying fungi isolated from karstic caves. Ecol Eng. 2017;103:106-17.

22. Yin $K$, Wang $Q$, Lv M, Chen L. Microorganism remediation strategies towards heavy metals. Chem Eng J. 2019;360:1553-63.

23. Beazley MJ, Martinez RJ, Sobecky PA, Webb SM, Taillefert M. Uranium biomineralization as a result of bacterial phosphatase activity: insights from bacterial isolates from a contaminated subsurface. Environ Sci Technol. 2007:41(16):5701-7.

24. Ghorpade A, Ahammed MM. Water treatment sludge for removal of heavy metals from electroplating wastewater. Environ Eng Res. 2017;23:92-8.

25. Orescanin V, Durgo K, Mikelic IL, Halkijevic I, Kuspilic M. Toxicity assessment of untreated/treated electroplating sludge using human and plant bioassay. J Environ Sci Health A. 2018;53:925-30.

26. Scarazzato T, Panossian Z, Tenorio J, Perez-Herranz V, Espinosa D. A review of cleaner production in electroplating industries using electrodialysis. J Clean Prod. 2017:168:1590-602.

27. Zhou C, Ge S, Yu H, Zhang T, Cheng H, Sun Q, Xiao R. Environmental risk assessment of pyrometallurgical residues derived from electroplating and pickling sludges. J Clean Prod. 2018;177:699-707.

28. Hu K, Xu D, Chen Y. An assessment of sulfate reducing bacteria on treating sulfate-rich metal-laden wastewater from electroplating plant. J Hazard Mater. 2020. https://doi.org/10.1016/122376.

29. Ye J, Yin H, Mai B, Peng H, Qin H, He B, Zhang N. Biosorption of chromium from aqueous solution and electroplating wastewater using mixture of Candida lipolytica and dewatered sewage sludge. Bioresour Technol. 2010; 101(11):3893-902

30. Dhal B, Thatoi HN, Das NN, Pandey BD. Environmental quality of the BoulaNuasahi chromite mine area in India. Mine Water Environ. 2011;30:191-6.

31. Nordstrom DK, Blowes DW, Ptacek CJ. Hydrogeochemistry and microbiology of mine drainage: an update. Appl Geochem. 2015;57:3-16. 
32. Johnson DB, Hallberg KB. Acid mine drainage remediation options: a review. Sci Total Environ. 2005;338(1):3-14.

33. Song $Y$, Wang $H$, Yang J, Zhou L. Evaluation and optimization of a new microbial enhancement plug-flow ditch system for the pretreatment of acid mine drainage: semi-pilot test. RSC Adv. 2018;8(2):1039-46.

34. Nielsen G, Hatam I, Abuan KA, Janin A, Coudert L, Blais JF, Mercier G, Baldwin SA. Semi-passive in-situ pilot scale bioreactor successfully removed sulfate and metals from mine impacted water under subarctic climatic conditions. Water Res. 2018;140:268-79.

35. Elahi A, Arooj I, Bukhari DA, Rehman A. Successive use of microorganisms to remove chromium from wastewater. Appl Microbiol Biotechnol. 2020;104:3729-43.

36. EFSA Panel on Contaminants in the Food Chain (CONTAM). Scientific opinion on the risks to public health related to the presence of chromium in food and drinking water. EFSA J. 2014;12(3):3595.

37. Tripathi M, Garg SK. Dechlorination of chloroorganics, decolorization, and simultaneous bioremediation of $\mathrm{Cr}^{6+}$ from real tannery effluent employing indigenous Bacillus cereus isolate. Environ Sci Pollut Res. 2014;21(7):5227-41.

38. Hüffer $\mathrm{S}$, Taeger T. Sustainable leather manufacturing a topic with growing importance. J Am Leather Chem Assoc. 2004;99(10):423-8.

39. Sharma S, Malaviya P. Bioremediation of tannery wastewater by chromium resistant novel fungal consortium. Ecol Eng. 2016;91:419-25.

40. Chen L, Luo S, Xiao X, Guo H, Chen J, Wan Y, Li B, Xu T, Xi Q, Rao C, Liu C, Zeng GM. Application of plant growth-promoting endophytes (PGPE) isolated from Solanum nigrum L. for phytoextraction of Cd-polluted soils. Appl Soil Ecol. 2010;46:383-9.

41. Fan M, Liu Z, Nan L, Wang E, Chen W, Lin Y, Wei G. Isolation, characterization, and selection of heavy metal-resistant and plant growthpromoting endophytic bacteria from root nodules of Robinia pseudoacacia in a $\mathrm{Pb} / \mathrm{Zn}$ mining area. Microbiol Res. 2018;217:51-9.

42. Bayat B, Sari B. Comparative evaluation of microbial and chemical leaching processes for heavy metal removal from dewatered metal plating sludge. Hazard Mater. 2010;174(1-3):763-9.

43. Wu P, Zhang LJ, Lin C, Xie X, Yong X, Wu X, Zhou J, Jia H, Wei P. Extracting heavy metals from electroplating sludge by acid and bioelectrical leaching using Acidithiobacillus ferrooxidans. Hydrometallurgy. 2020;191:105225.

44. Zhou W, Zhang L, Peng J, Ge Y, Tian Z, Sun J, Cheng H, Zhou H. Cleaner utilization of electroplating sludge by bioleaching with a moderately thermophilic consortium: a pilot study. Chemosphere. 2019:232:345-55.

45. Choi HJ, Lee SM. Heavy metal removal from acid mine drainage by calcined eggshell and microalgae hybrid system. Environ Sci Pollut Res. 2015;22(17): 13404-11.

46. He M, Wang X, Wu F, Fu Z. Antimony pollution in China. Sci Total Environ. 2012:421:41-50

47. Sun W, Xiao E, Kalin M, Krumins V, YiranDong Y, Ning Z, Liu T, MinSun M, Zhao Y, Wu S, Mao J, Xiao T. Remediation of antimony-rich mine waters: assessment of antimony removal and shifts in the microbial community of an onsite field-scale bioreactor. Environ Pollut. 2016;215:213-22.

48. Samuel J, Paul ML, Pulimi M, Nirmala J. Hexavalent chromium bioremoval through adaptation and consortia development from Sukinda chromite mine isolates. Ind Eng Chem Res. 2012;51(9):3740-9.

49. Wang YS, Pan ZY, Lang JM, Xu JM, Zheng YG. Bioleaching of chromium from tannery sludge by indigenous Acidithiobacillus thiooxidans. J Hazard Mater. 2007:147(1-2):319-24.

50. Goswami S, Mazumder D. Treatment of chrome tannery wastewater by biological process-a mini review. Int J Environ Chem Ecol Geol Geophys Eng. 2013;7(11):522-8.

51. World Health Organization (2004) Chromium in drinking water. http://www. who.int/water_sanitation_health/dwq/chemicals/chromium.pdf.

52. Gupta P, Rani R, Chandra A, Varjani S, Kumar V. The Role of Microbes in Chromium Bioremediation of Tannery Effluent. In: Bui XT, Chiemchaisri C, Fujioka T, Varjani S. (eds) Water and Wastewater Treatment Technologies. Energy, Environment, and Sustainability. Singapore: Springer; 2019. https:/ doi.org/10.1007/978-981-13-3259-3_17.

53. Yadav S, Shukla OP, Rai UN. Chromium pollution and bioremediation. EnviroNews Newslett. 2005;11:1.

54. Ahmed E, Abdulla HM, Mohamed AH, El-Bassuony AD. Remediation and recycling of chromium from tannery wastewater using combined chemicalbiological treatment system. Process Saf Environ Prot. 2016;104:1-10.

55. Ma H, Zhou J, Hua L, Cheng F, Zhou L, Qiao X. Chromium recovery from tannery sludge by bioleaching and its reuse in tanning process. J Clean Prod. 2017;142:2752-60.
56. Liu H, Wang Y, Zhang H, Huang G, Yang Q, Wang Y. Synchronous detoxification and reduction treatment of tannery sludge using $\mathrm{Cr}(\mathrm{VI})$ resistant bacterial strains. Sci Total Environ. 2019;687:34-40.

57. Xiao X, Luo S, Zeng G, Wei W, Wan Y, Chen L, Guo H, Cao Z, Yang L, Chen J, Xi Q. Biosorption of cadmium by endophytic fungus (EF) Microsphaeropsis sp. LSE10 isolated from cadmium hyperaccumulator Solanum nigrum L. Bioresour Technol. 2010;101:1668-74.

58. Luo S, Wan Y, Xiao X, Guo H, Chen L, Xi Q, Zeng G, Liu C, Chen J. Isolation and characterization of endophytic bacterium LRE07 from cadmium hyperaccumulator Solanum nigrum L. and its potential for remediation. App Microbiol Biotechnol. 2011;89:1637-44.

59. Chen L, Luo S, Li X, Wan Y, Chen J, Liu C. Interaction of Cdhyperaccumulator Solanum nigrum $\mathrm{L}$. and functional endophyte Pseudomonas sp. Lk9 on soil heavy metals uptake. Soil Biol Biochem. 2014; 68:300-8.

60. Shin MN, Shim J, You Y, Myung H, Bang SK, Cho M, Kamala-Kannan S, Oh BT. Characterization of lead resistant endophytic Bacillus sp. MN3-4 and its potential for promoting lead accumulation in metal hyperaccumulator Alnus firma. J Hazard Mater. 2012;199:314-20.

61. Luo S, Chen L, Chen JL, Xiao X, Xu T, Wan Y, Rao C, Liu C, Liu Y, Lai C, Zeng GM. Analysis and characterization of cultivable heavy metal-resistant bacterial endophytes isolated from Cd-hyperaccumulator Solanum nigrum L. and their potential use for phytoremediation. Chemosphere. 2011;85:1130-8.

62. Płociniczak T, Chodor M, Pacwa-Płociniczak M, Piotrowska-Seget Z. Metaltolerant endophytic bacteria associated with Silene vulgaris support the $\mathrm{Cd}$ and Zn phytoextraction in non-host plants. Chemosphere. 2019:219:250-60

63. Wang Q, Ma L, Zhou Q, Chen B, Zhang X, Wu Y, Pan F, Huang L, Yang X, Feng $Y$. Inoculation of plant growth promoting bacteria from hyperaccumulator facilitated non-host root development and provided promising agents for elevated phytoremediation efficiency. Chemosphere. 2019;234:769-76.

64. Bilal S, Shahzad R, Khan AL, Al-Harrasi A, Kim CK, Lee IJ. Phytohormones enabled endophytic Penicillium funiculosum LHL06 protects Glycine max L. from synergistic toxicity of heavy metals by hormonal and stress-responsive proteins modulation. J Hazard Mater. 2019:379:120824.

65. Ashraf S, Afzal M, Naveed M, Shahid M, Ahmad ZZ. Endophytic bacteria enhance remediation of tannery effluent in constructed wetlands vegetated with Leptochloa fusca. Int J Phytoremediat. 2018;20(2):121-8.

66. Hussain Z, Arslan M, Malik MH, Mohsin M, labal S, Afzal M. Treatment of the textile industry effluent in a pilot-scale vertical flow constructed wetland system augmented with bacterial endophytes. Sci Total Environ. 2018;645: 966-73.

67. Burges A, Epelde L, Blanco F, Becerril JM, Garbisu G. Ecosystem services and plant physiological status during endophyte-assisted phytoremediation of metal contaminated soil. Sci Total Environ. 2017;584:329-38.

68. Wang $L$, Lin $H$, Dong $Y, L i B$, He Y. Effects of endophytes inoculation on rhizosphere and endosphere microecology of Indian mustard (Brassica juncea) grown in vanadium contaminated soil and its enhancement on phytoremediation. Chemosphere. 2020;240:124891.

69. Potysz A, Lens PNL, van de Vossenberg J, Rene ER, Grybos M, Guibaud G, Kierczak J, van Hullebusch ED. Comparison of $\mathrm{Cu}, \mathrm{Zn}$ and Fe bioleaching from Cu-metallurgical slags in the presence of Pseudomonas fluorescens and Acidithiobacillus thiooxidans. Appl Geochem. 2016;68:39e52.

70. Funari V, Makinen J, Salminen J, Braga R, Dinelli E, Revitzer H. Metal removal from municipal solid waste incineration fly ash: a comparison between chemical leaching and bioleaching. Waste Manag. 2017;60:397-406.

71. Shah SS, Palmieri MC, Regina S, Sponchiado P, Bevilaqua D. Environmentally sustainable and cost-effective bioleaching of aluminum from low-grade bauxite ore using marine-derived Aspergillus niger. Hydrometallurgy. 2020; 195:105368.

72. Li Q, Laszlo JC, Geoffrey MG. Biomineralization of metal carbonates by Neurospora crassa. Environ Sci Technol. 2014;24:14409-16.

\section{Publisher's Note}

Springer Nature remains neutral with regard to jurisdictional claims in published maps and institutional affiliations. 